3. Вашуленко М. С. Державний освітній стандарт 3 української мови (початкова ланка) / М. С. Вашуленко // Початкова школа. - 1997. - №3. - С. 44. 4. Декларація принципів толерантності // Національна комісія України у справах ЮНЕСКО. - К.,1995. - 14 с. 5. Зеер Э. Ф. Компетентностный подход к образованию / Э. Ф. Зеep // http: //www urorao.ru. 6. Кремень В. Г. Освіта і наука визначають авторитет держави / В. Г. Кремень // Історія в школах України. - 2002. - С. 2-4. 7. Овчарук О. В. Компетентності як ключ до оновлення змісту освіти / О. В. Овчарук // Стратегія реформування освіти в Україні: Рекомендації з освітньої політики. - К. : «К. І. С.», 2003. - 296 с. 8. Пометун О. І. Формування громадянської компетентності: погляд 3 позиції сучасної педагогічної науки / О. І. Пометун //Вісник програм шкільних обмінів. - 2005. - № 23. - С. 18. 9. Савченко О. Я. Удосконалення професійної підготовки майбутніх учителів початкових класів / О. Я. Савченко // Початкова школа. - 2001. - №7. - С. 3. 10. Словник іншомовних слів. - К. : Довіра, УНВЦ «Рідна мова», 2000. - 101 с. 11. Хуторской А. Ключевые компетенции как компонент личностно-ориентированной парадигмы образования / А. Хуторской // Народное образование. - 2003. - № 2. - С. 58-64.

Діна Тюріна

\title{
ОБГРУНТУВАННЯ ТЕХНОЛОГІЇ ФОРМУВАННЯ ВМІНЬ МОДЕЛЮВАННЯ У СТУДЕНТІВ ВИЩИХ ЕКОНОМІЧНИХ НАВЧАЛЬНИХ ЗАКЛАДІВ У ПРОЦЕСІ САМОСТІЙНОЇ НАВЧАЛЬНОЇ ДІЯЛЬНОСТІ
}

Тюріна Д. М. Обгрунтування технології формування вмінь моделювання у студентів вищих економічних навчальних закладів у процесі самостійної навчальної діяльності.

У статті запропоновано та обгрунтовано технологію формування вмінь моделювання у студентів вищих економічних навчальних закладів у процесі самостійної навчальної діяльності, що передбачає визначення груп умінь моделювання та полягає в реалізації мотиваційнопізнавального, тренувально-діяльнісного, рефлексивно-творчого етапів.

Ключові слова: моделювання, самостійна навчальна діяльність, технологія, уміння, студент, вищий економічний навчальний заклад.

Тюрина Д. Н. Обоснование технологии формирования умений моделирования у студентов высших экономических учебных заведений в процессе самостоятельной учебной деятельности.

В статье предложена и обоснована технология формирования умений моделирования у студентов высших экономических учебных заведений в процессе самостоятельной учебной деятельности, который предусматривает определение групп умений моделирования и заключается в реализации мотивационно-познавательного, тренировочно-деятельностного, рефлексивно-творческого этапов.

Ключевые слова: моделирование, самостоятельная учебная деятельность, технология, умение, студент, высшее экономическое учебное заведение.

Turina D. M. Justification technology skills formation modeling in students of higher economic education in the process of self-learning activities.

The author of the thesis is devoted to technology of modeling skills in students of higher economic education in the independent educational activity that involves identifying groups of skills and modeling is to implement motivational and educational, training-active, reflective and creative stages.

Key words: modeling, independent learning activities, technology, skills, student, higher economic institution.

На сучасному етапі розвитку української державни, інтеграції країни до світового співтовариства, активізації зовнішньоекономічних зв'язків значно зросла потреба у кваліфікованих фахівцях, спроможних якісно й творчо виконувати свої професійні обов'язки. Актуальності набуває завдання з підготовки кадрів нової формації в галузі економіки й фінансів. Аналіз Концепції розвитку економічної освіти України переконує, що в умовах складності та комплексності об'єктів, невизначеності та багатофакторності економічних процесів важливого значення для випускників економічних вищих навчальних закладів набуває сформованість умінь аналізувати й моделювати економічні ситуації в мікро- й макропредметному середовищі. 
Сучасний економіст повинен уміти самостійно шукати й знаходити необхідну інформацію, визначати проблеми, будувати гіпотези, розпізнавати в сукупностях даних певні закономірності, приймати обгрунтовані управлінські рішення. Великого значення в становленні майбутніх фахівців економічного профілю набуває вміння обгрунтовувати, розробляти, використовувати в практичній діяльності моделі досліджуваних об'єктів. Водночас результати пілотажного дослідження свідчать, що 52,2 \% від 385 майбутніх спеціалістів недостатньо володіють уміннями моделювання економічних об'єктів, а саме: самостійно визначати мету, розробляти моделі, аналізувати отримані результати. Тільки $36,5 \%$ із 52 опитаних викладачів усвідомлюють необхідність формування у студентів зазначених вище вмінь, але часто не співвідносять зміст навчального матеріалу з доцільністю здійснення цієї роботи. Ці дані надають змогу стверджувати, що розв'язання проблеми формування вмінь моделювання у студентів вищих економічних навчальних закладів $\epsilon$ актуальною вимогою сьогодення.

Проблему використання моделей і методів моделювання в підготовці майбутніх фахівців досліджували О. Власенко, Ю. Кулюткін, І. Левіна, М. Махмутов, В. Паламарчук, Л. Панченко, К. Рум'янцева, I. Теплицький, Л. Фрідман, В. Штофф та інші. На перевагах упровадження засобів моделювання в процес підготовки спеціалістів економічного профілю наголошують Л. Нічуговська, Г. Савченко. У працях науковців наголошено на тому, що застосування вміння моделювання в навчальному процесі сприяє підвищенню результативності навчальної діяльності студентів і рівня сформованості вмінь самостійної навчальної діяльності, а також здатності до самооцінки, самоорганізації й самоконтролю.

Нині Міністерство освіти і науки України орієнтує вищі навчальні заклади на зменшення тижневого аудиторного навчального навантаження студентів і водночас на збільшення часу на індивідуальну та самостійну роботу. Проблему організації самостійної роботи досліджувало багато науковців, зокрема О. Алексюк, Ю. Бабанський, В. Євдокимов, В. Козаков, І. Лернер, О. Малихін, М. Махмутов, І. Огородніков, Н. Половнікова, П. Підкасистий, М. Скаткін.

Підготовку майбутніх фахівців економічного профілю вивчали Г. Дутка, І. Зайцева, Н. Захарченко, В. Стрельніков. Питанням самостійної роботи студентів-економістів приділяли увагу Н. Ванжа, Я. Галета, С. Кустовський, С. Малихіна, Г. Романова, М. Смирнова. Водночас у педагогічній науці недостатньо висвітлено проблему формування вмінь моделювання у процесі самостійної навчальної діяльності студентів, зокрема вищих економічних навчальних закладів.

Актуальність і доцільність розв'язання означеної проблеми посилюються наявними в сучасній вищій освіті суперечностями, зокрема між: функціональними вимогами, що висуваються до економістів, і рівнем їхньої підготовки до розв'язання професійних завдань методом моделювання; необхідністю забезпечення підготовки майбутніх економістів до моделювання економічних об'єктів і недостатнім використанням для цього можливостей самостійної навчальної діяльності; потребою у сформованості вмінь моделювання в майбутніх фахівців економічного профілю та відсутністю технологій формування вмінь моделювання у студентів вищих економічних навчальних закладів. Саме тому порушена нами тема $\epsilon$ актуальною і потребує свого розв'язання в нових історичних умовах.

Мета статmi - теоретично обгрунтувати сутність і структуру педагогічної технології формування вмінь моделювання у студентів вищих економічних навчальних закладів у процесі самостійної навчальної діяльності.

Поняття «педагогічна технологія» у вітчизняній педагогічній науці з'явилося порівняно недавно - у 20-х pp. ХX ст. (І. Павлов, В. Бехтерев, О. Ухтомський, С. Шацький) і трансформувалося в об'єкт поглиблених наукових пошуків лише на початку 80-х pp. XX ст. Результати дослідження свідчать про неоднозначність трактування зазначеної категорії сучасними дослідниками, тому видається доцільним навести найбільш поширені підходи до формулювання дефініції «педагогічна технологія».

Педагогічна технологія, згідно $з$ концепцією В. Беспалько, трактується як проект певної педагогічної системи, який реалізується на практиці [1]. М. Махмутов визначає педагогічну технологію як «більш або менш жорстко запрограмований (алгоритмізований) процес взаємодії викладача й учнів, який гарантує досягнення поставленої мети» [7]. Н. Мойсеюк пропонує таке визначення поняття «педагогічна технологія»: «науково обгрунтована педагогічна (дидактична) система, яка гарантує досягнення певної навчальної мети шляхом неухильного виконання визначеної послідовності взаємодій учителя й учнів, використання відповідної сукупності 
методів і форм навчання в умовах оперативного контролю й оцінювання проміжних результатів процесу навчання, їx корекції» [8]. Л. Товажнянський i О. Романовський визначають педагогічну технологію як «послідовну, взаємопов'язану систему дій, операцій і процедур, виконуваних педагогом і спрямованих на розв'язання педагогічних завдань, або як планомірне й послідовне втілення на практиці заздалегідь спроектованого педагогічного процесу, що має на меті досягнення конкретного, діагностованого й гарантованого результату» [9].

I. Прокопенко та В. Євдокимов педагогічну технологію розглядають як систему науково обгрунтованих дій і взаємодій елементів навчального процесу, виконання яких гарантує досягнення визначеної мети навчання [10].

О. Степанов і М. Фіцула стверджують, що педагогічна технологія - це сукупність психолого-педагогічних настанов, які визначають спеціальний підхід і композицію форм, методів, способів, прийомів і виховних засобів [11].

Незважаючи на різні підходи до визначення сутності педагогічних технологій, ми поділяємо думку Г. Ковальчук, яка зазначає, що спільним у більшості авторів є розуміння того, що використання педагогічних технологій передбачає:

1) цілеорієнтоване моделювання навчальних ситуацій, на основі яких послідовно реалізуються зміст і мета навчальної діяльності;

2) використання організаційних умов, наукових ідей і засобів діяльності, які забезпечують оптимізацію всього навчально-виховногопроцесу;

3) активізацію діяльності всіх учасників педагогічного процесу, розвиток суб'єктсуб'єктних стосунків, посилення гуманістичного і творчого підходів у навчальному процесі [5].

У наукових працях визначено, що науково й практично обгрунтованій технології притаманні такі ознаки: поділ процесу на взаємопов'язані етапи; координоване й поетапне виконання дій, спрямованих на досягнення результату (мети) пошуку; однозначність виконання процедур і операцій, які входять до складу технології, що є найважливішою умовою досягнення результатів, які відповідають поставленій меті.

Отже, розробляючи технологію формування вмінь моделювання у студентів вищих економічних навчальних закладів у процесі самостійної навчальної діяльності, ми спиралися на розуміння цього поняття як сукупності етапів, а також адекватних їм засобів, форм і методів, зокрема контролю й коригування результату, застосування яких у процесі підготовки фахівців економічних спеціальностей гарантує досягнення поставленої мети.

Розроблення зазначеної педагогічної технології передбачає обгрунтування ії структури. Результатом аналізу наукових джерел Т. Бутенко, М. Гриньової, І. Дичківської, Л. Іванченко, В. Корнещук, А. Кучер, П. Матвієнко, Г. Селевко, Л. Сметаніної, здійсненого у процесі дослідження, стало виокремлення структурних складників педагогічної технології формування вмінь моделювання у студентів вищих економічних навчальних закладів у процесі самостійної навчальної діяльності: концептуальна частина - передбачає короткий опис провідних (головних) ідей, положень, підходів і принципів, які сприяють її розумінню; змістово-цільова частина - охоплює постановку мети, формулювання цілей (завдань) щодо досягнення результатів, зміст навчального матеріалу; процесуальна частина - організація навчального процесу відповідно до поставленої мети й завдань (етапи формування, методи й форми навчальної діяльності); програмно-методичне забезпечення (навчальні дисципліни, програми, навчальні та методичні посібники, дидактичний матеріал); діагностувальна частина - оцінка якості навчального процесу, діяльності викладача й діяльності студентів, діагностика одержаних результатів, їх співвідношення 3 поставленою метою i завданням (інструментарій для діагностики результативності навчального процесу - критерії оцінки, рівні сформованості, результат).

Зважаючи на викладене вище, можна зазначити, що всі структурні складники цієї педагогічної технології - концептуальний, змістово-цільовий, процесуальний, діагностувальний не просто механічно поєднуються в певний комплекс, а утворюють єдину систему, у якій кожна частина підпорядковується іншій і водночас визначає ії зміст: мета технології, що грунтується на певних концептуальних положеннях, визначає її зміст, а зміст у свою чергу - вибір засобів і методів навчання. Діагностувальний і процесуальний складники пов'язані між собою, оскільки на кожному етапі технології, поки не буде досягнутий результат, за допомогою рефлексії і системи контролю перевіряється сформованість набутих знань, умінь і навичок. Якщо було досягнуто позитивного результату за тим чи іншим діагностувальним компонентом, то 
реалізація педагогічної технології припиняється; якщо результат негативний - відбувається повернення до процесуального компонента. У цьому випадку за допомогою педагогічних умов здійснюється корекція хибного рівня та перехід до процесу формування наступного, доки не буде досягнуто позитивного результату. Отже, є підстави стверджувати, що структурні елементи цієї технології є ії системотворчими компонентами [6].

Відповідно до структури педагогічної технології ми обгрунтуємо розроблену нами педагогічну технологію, спрямовану на формування вмінь моделювання у студентів економічних спеціальностей у процесі самостійної навчальної діяльності.

Концептуальні засади запропонованої педагогічної технології полягають у дотриманні припущення, що ефективність формування вмінь моделювання у студентів вищих економічних навчальних закладів у процесі самостійної навчальної діяльності забезпечується розробленням та запровадженням науково обгрунтованої технології, яка передбачає формування груп умінь моделювання (гностичні, проектувально-конструктивні, дослідницько-творчі, оціннорефлексивні) відповідно до складників процесу моделювання (постановка завдання моделювання; розроблення моделі; реалізація та аналіз моделі; рефлексія) і має три етапи: мотиваційно-пізнавальний; тренувально-діяльнісний; рефлексивно-творчий.

Окрім того, основа запропонованої педагогічної технології полягає в дотримані вимог до формування вмінь моделювання у студентів економічних спеціальностей у процесі самостійної навчальної діяльності: формування мотивації до навчальної діяльності, спрямованої на розвиток пізнавальних, професійних, творчих мотивів; забезпечення орієнтовної основи діяльності студентів у процесі моделювання, тобто опис етапів моделювання і послідовності їхнього виконання; забезпечення поступового переходу управління навчальною діяльністю від прямого управління до співуправління та самоуправління; застосування задачного підходу, тобто використання в навчальному процесі системи завдань, яка побудована відповідно до етапів процесу моделювання, спрямована на поетапне формування вмінь моделювання, передбачає поступове відпрацювання кожного елемента вміння моделювати на підставі міжпредметних зв'язків; активізація процесу рефлексії результатів діяльності моделювання економічних об'єктів, процесів та явищ, яка передбачає прогнозування як результатів виконаної дії, так і спосіб ï̈ виконання.

Окрім того, розроблення педагогічної технології має грунтуватися на таких принципах: наочності, системності, активності, мотиваційного забезпечення, безперервності, науковості, професійної спрямованості.

Щодо змістово-цільового блоку, то головною метою педагогічної технології є формування вмінь моделювання у студентів вищих економічних навчальних закладів у процесі самостійної навчальної діяльності. Зазначеній меті підпорядковуються часткові завдання, які іiі конкретизують на кожному з етапів технології.

Реалізація етапів та ефективне досягнення виокремлених цілей і завдань здійснювалися за допомогою процесуального компонента педагогічної технології.

Процесуальний блок педагогічної технології передбачає такі етапи:

1) мотиваційно-пізнавальний (спрямований на усвідомлення студентами необхідності набуття теоретичних знань і доцільності практичного використання вмінь моделювання у процесі самостійної навчальної діяльності; засвоєння студентами необхідних знань про сутність моделювання, види, функції, особливості, складники процесу моделювання);

2) тренувально-діяльнісний (передбачає набуття майбутніми фахівцями гностичних, проектувальноконструктивних, дослідницько-творчих, оцінно-рефлексивних умінь моделювання);

3) рефлексивно-творчий (забезпечує набуття досвіду творчого використання вмінь моделювання; оцінку, самооцінку й самокорегування знань і вмінь щодо моделювання економічних об'єктів).

Реалізація кожного із зазначених етапів передбачає визначення мети, добір завдань, методів та форм організації навчальної діяльності студентів, засобів управління їхньою діяльністю, застосування вправ і завдань, ділових і рольових ігор, тренінгових програм, наближених до реальних умов професійної діяльності майбутніх фахівців економічного профілю.

Необхідним складником педагогічної технології $є$ перевірка її дієвості та ефективності діагностувальний компонент педагогічної технології. Діагностування результатів формування вмінь моделювання під час реалізації педагогічної технології відбувалося в ході поетапного та підсумкового контролю на основі розроблених критеріїв і показників сформованості вмінь 
моделювання в єдності компонентів: мотиваційного (сформованість мотивів до навчальної діяльності), когнітивного (рівень засвоєння студентами знань, необхідних для здійснення моделювання), процесуального (сформованість визначених груп умінь моделювання; самостійність застосування моделювання).

До діагностувального компонента відносимо також рефлексію студента і викладача, оскільки результати проміжного контролю допомагають виявити й усвідомити допущені у процесі роботи помилки кожного учасника технології та запустити необхідні механізми корекції. На кожному етапі впровадження технології студент розробляв певний освітній продукт, який міг бути оцінений викладачем, що давало змогу молодій людині зробити висновки щодо сформованості знань і необхідності їх корекції [11].

Визначену технологію формування вмінь моделювання у студентів вищих економічних навчальних закладів у процесі самостійної навчальної діяльності ілюструє рис. 1.

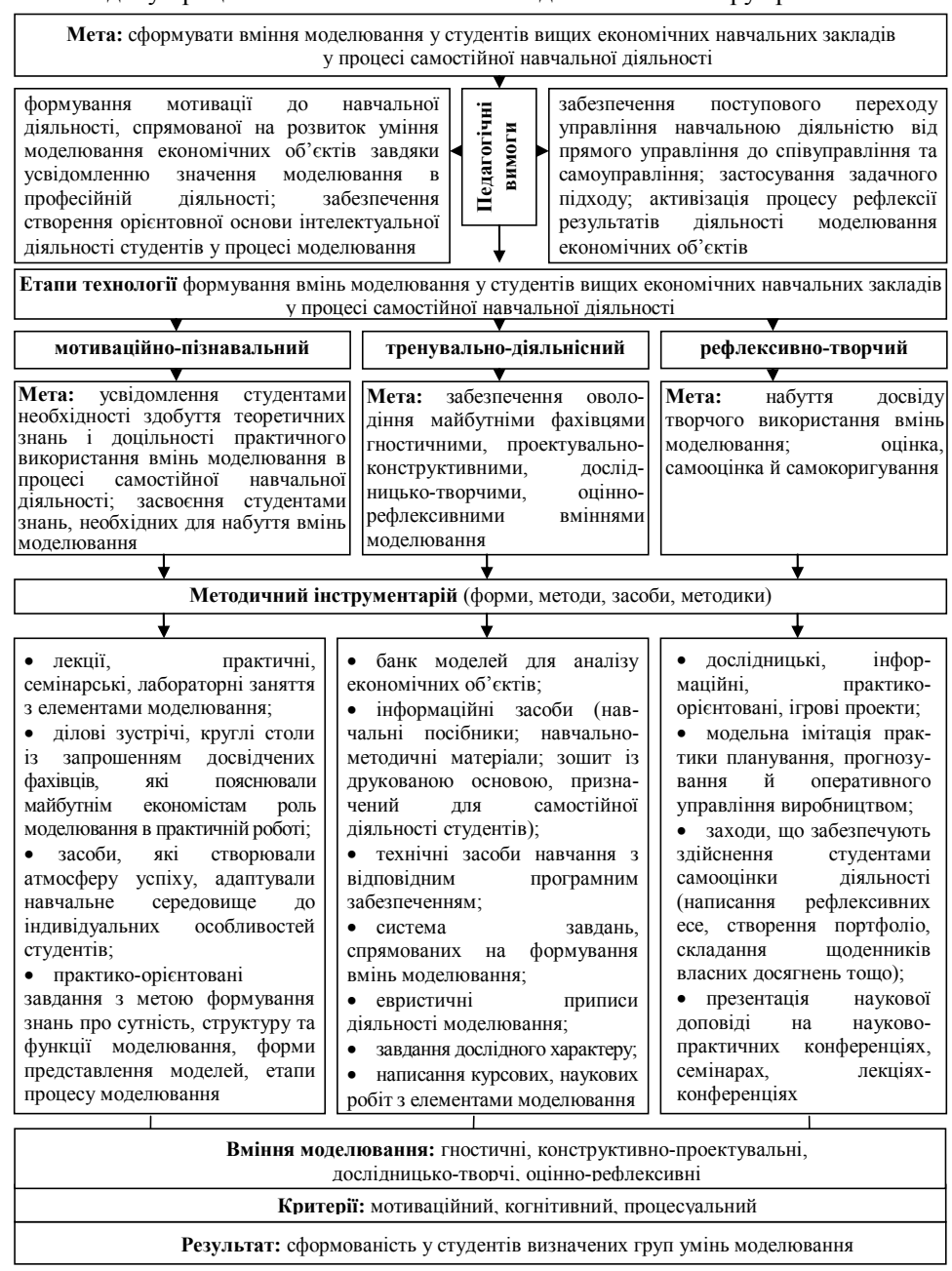

Рис. 1. Технологія формування вмінь моделювання у студентів вищих економічних навчальних закладів у процесі самостійної навчальної діяльності 
На грунті здійсненого у статті аналізу проблеми педагогічної технології формування вмінь моделювання у студентів вищих економічних навчальних закладів у процесі самостійної навчальної діяльності робимо висновки про необхідність упровадження технології в практику задля розвитку групи умінь моделювання (гностичні, проектувально-конструктивні, дослідницько-творчі, оцінно-рефлексивні) у студентів економічних спеціальностей. Установлені структурні частини цієї технології є ії системоутворювальними компонентами. Відповідно до структури педагогічної технології розроблено технологію, що передбачає формування груп умінь моделювання (гностичні, проектувально-конструктивні, дослідницькотворчі, оцінно-рефлексивні) і має три етапи: мотиваційно-пізнавальний; тренувальнодіяльнісний; рефлексивно-творчий. Для кожного етапу визначено мету, завдання, методи та форми організації навчальної діяльності студентів, засоби управління їхньою діяльністю.

Визначена й теоретично обгрунтована структура педагогічної технології може слугувати теоретичним підгрунтям для організації експериментальної роботи щодо оволодіння вказаними зазначеними вміннями. Подальші дослідження передбачається здійснити в напрямку поглибленого вивчення процесуальної частини педагогічної технології формування вмінь моделювання у студентів вищих економічних навчальних закладів у процесі самостійної навчальної діяльності.

1. Беспалько В. П. Слагаемые педагогической технологии / В. П. Беспалько. - М. : Педагогика, 1988. - 192 с. 2. Бутенко Т. О. Обгрунтування педагогічної технології формування комунікативної компетентності майбутніх інженерів [Електронний ресурс]/ Т. О. Бутенко // Режим доступу: http://www.nbuv.gov.ua/portal/soc_gum/pfto/2009_3/files/ped_2009_03_16_Butenko.pdf. 3. Гриньова М. В. Педагогічні технології: теорія та практика : [навч.-метод. посіб.] / за ред. проф. М. В. Гриньової. Полтава : ACMI, 2008. - 230 с. 4. Дичківська І. М. Інноваційні педагогічні технології / І. М. Дичківська. - К. : Академвидав, 2004. - 352 с. 5. Ковальчук Г. О. Формування професійних педагогічних умінь у студентів - майбутніх викладачів економіки : автореф. дис. на здобуття наук. ступеня канд. пед. наук: спец. 13.00.04 «Теорія і методика професійної освіти» / Г. О. Ковальчук. - К., 1999. - 18 с. 6. Кучер А. В. Структура педагогічної технології формування вмінь професійного спілкування [Електронний ресурс]// Режим доступу: http://archive.nbuv.gov.ua /portal/Soc_Gum /Vlush/Ped/2011_20_2/26.pdf. 7. Махмутов М. И. Педагогические технологи развития мышления / М. И. Махмутов, Г. И. Ибрагимов. - Казань, 1993. - 88 с. 8. Мойсеюк Н. Є. Педагогіка : [навч. посіб.] / Н. С. Мойсеюк. - [5-е вид.]. -К., 2007. - 656 с. 9. Основы педагогики высшей школы : [учеб. пособ.] / Л. Л. Товажнянский [и др.]. - Харьков : НТУ «ХПИ», 2005. - 600 с. 10. Прокопенко І. Ф. Педагогічні технології : [навч. посіб.] / І. Ф. Прокопенко, В. І. Євдокимов. - Х. : Колегіум, 2005. - 224 с. 11. Степанов О. М. Основи психології і педагогіки : [посібник] /О. М. Степанов, М. М. Фіцула. - К. : Академвидав, 2003. -504 с.

Оксана Цигуль

\section{ОСОБЛИВОСТІ ФОРМУВАННЯ СКЛАДНИКІВ ІНШОМОВНОЇ КОМПЕТЕНТНОСТІ У СТУДЕНТІВ ІНЖЕНЕРНОЇ СПЕЦАЛЬНОСТІ}

Цигуль О. В. Особливості формування складників іншомовної компетентності у студентів інженерної спеціальності.

У статті на основі аналізу наукової літератури визначаються та характеризуються структурні компоненти (комунікативний, соціолінгвістичний, прагматичний) іншомовної компетентності, окреслюються шляхи їх формування у студентів інженерної спеціальності.

Ключові слова: іншомовна компетентність, комунікативна компетенція, соціолінгвістична компетенція, прагматична компетенція.

Цыгуль О. В. Особенности формирования составляющих иноязычной компетентности у студентов инженерной специальности.

В статье на основе анализа научной литературы определяются и характеризуются структурные компоненты (коммуникативный, социолингвистический, прагматический) иноязычной компетентности, намечаются пути их формирования у студентов инженерной специальности.

Ключевые слова: иноязычная компетентность, коммуникативная компетенция, социолингвистическая компетенция, прагматическая компетенция. 